\title{
Nutritional management and sexual condition in cattle determine differentiation in the fatty acid profile of meat
}

\section{Práticas nutricionais e condição sexual em bovinos determinam diferenciação no perfil de ácidos graxos da carne}

\author{
Jonatas Cattelam ${ }^{1 *}$; Flânia Mônego Argenta2; Dari Celestino Alves Filho3; \\ Ivan Luiz Brondani ${ }^{3}$; José Laerte Nörnberg ${ }^{3}$; Rangel Fernandes Pacheco ${ }^{4}$; \\ Andrei Retamoso Mayer ; Diego Soares Machado6; Odilene de Souza Teixeira7; \\ Daniele Borchate ${ }^{8}$
}

\section{Highlights}

Diet based on rice grain produces meat with higher omega- 3 content in cattle.

Heifers finished with high-grain diets produce meat with a higher CLA than steers.

Heifers have a better omega-6/omega-3 fatty acids ratio in the meat than steers.

Polyunsaturated fatty acids showed an interaction between diet and sexual condition.

\begin{abstract}
This study aimed at evaluating the fatty acid profile of meat from feedlot finished heifers and steers fed with high-grain diets. It was used 45 Charolais and Nellore crossbred cattle, 21 of them were heifers with an initial age of $32 \pm 2$ months and $359.9 \pm 6.7 \mathrm{~kg}$ of body weight, and 24 were steers with an initial age of $20 \pm 2$ months and $337.6 \pm 6.2 \mathrm{~kg}$ of body weight. The animals were distributed in the treatments according to the energy source used in the diet, being them: rice, white oats or corn, using seven heifers and eight

1 Prof. Dr., Universidade Federal da Fronteira do Sul, UFFS, Campus of Realeza, Realeza, PR, Brazil. E-mail: jonatas. cattelam@uffs.edu.br

2 Dr., Instituto Federal de Educação, Ciência e Tecnologia Farroupilha, IFFar, Campus São Vicente do Sul, São Vicente do Sul, RS, Brazil. E-mail: flania.argenta@iffarroupilha.edu.br

3 Profs. Drs., Universidade Federal de Santa Maria, UFSM, Santa Maria, RS, Brazil. E-mail: darialvesfilho@hotmail.com; ivanbrondani@gmail.com; jlnornberg@gmail.com

${ }^{4}$ Prof. Dr., Instituto Federal de Educação, Ciência e Tecnologia Farroupilha, IFFar, Campus Frederico Westphalen, RS, Brazil. E-mail: rangel.pacheco@iffarroupilha.edu.br

5 Prof. Dr., Universidade Nilton Lins, Manaus, AM, Brazil. E-mail: andreirm@bol.com.br

6 Prof. Dr., Universidade Estadual de Santa Catarina, UDESC, Chapecó, SC, Brazil. E-mail: ds.machado@udesc.br

7 Prof. Dr., Instituto Federal de Educação, Ciência e Tecnologia de Mato Grosso do Sul, Campus Ponta Porã, MS, Brazil. E-mail: odilene_rs@hotmail.com

8 M.e, Universidade Federal de Santa Maria, UFSM, Santa Maria, RS, Brazil. E-mail: danieleborchate@gmail.com

* Author for correspondence
\end{abstract}

Received: July 23, 2020 - Approved: Apr. 20, 2021 
steers for each diet. The experimental design was completely randomized, with factorial arrangement $3 \times 2$ (three treatments and two sexual conditions). The diet based on corn provided higher levels of pentadecylic and margaric fatty acids. Excepting elaidic fatty acid, beef from steers and heifers was similar for the different saturated and monounsaturated fatty acids evaluated. A rice-based diet is advantageous when meat production is recommended with greater participation of fatty acids from the omega-3 group. When finished in feedlot with high-grain diets, the heifers produce meat with higher conjugated linoleic acid (CLA) content and a better ratio between omega-6/omega-3 fatty acids compared to steers. These findings indicate that it is possible to modify undesirable characteristics in meat through the nutritional management of animals, searching for a product that meets the requirements of a modern population, which is redefining its principles regarding food.

Key words: Conjugated linoleic acid. Corn. Heifers. Meat quality. Rice. White oats.

\section{Resumo}

O presente estudo objetivou avaliar o perfil de ácidos graxos da carne de novilhos e novilhas, terminados em confinamento e alimentados com dietas de alto grão. Utilizaram-se 45 bovinos, sendo 21 novilhas com idade inicial de $32 \pm 2$ meses e 359,9 $\pm 6,7 \mathrm{~kg}$, e 24 novilhos com idade inicial de $20 \pm 2$ meses e 337,6 $\pm 6,2 \mathrm{~kg}$, oriundos do cruzamento entre as raças Charolês e Nelore. Os animais foram distribuídos nos tratamentos conforme a fonte energética utilizada na dieta, sendo essas: arroz; aveia branca ou milho, sendo utilizados sete novilhas e oito novilhos para cada dieta alimentar. O delineamento experimental foi o inteiramente casualizado, com arranjo fatorial $3 \times 2$ (três tratamentos e duas condições sexuais). A dieta a base de milho proporcionou maiores teores de ácidos graxos pentadecílico e margárico. A exceção do ácido graxo elaídico, a carne de novilhos e novilhas foi similar para os distintos ácidos graxos saturados e monoinsaturados avaliados. A dieta a base de grão de arroz mostra-se vantajosa quando se preconiza a produção de carne com maior participação de ácidos graxos do grupo ômega 3. As novilhas, quando terminadas em confinamento com dietas de alto grão, produzem carne com maior teor de ácido linoleico conjugado (CLA) e melhor relação entre ácidos graxos ômega 6/ ômega 3 comparadas aos novilhos. Essas constatações indicam que é possível modificar as características indesejáveis da carne a partir do manejo nutricional dos animais, na busca por um produto que atenda as exigências da população moderna, que está redefinindo os seus princípios com relação a alimentação.

Palavras-chave: Ácido linoleico conjugado. Arroz. Aveia branca. Milho. Novilhas. Qualidade da carne.

\section{Introduction}

The eating habits of human beings are based on values and cultures, which undergo constant redefinitions. In this context, the current meat consumers are more concerned and demanding about health, making them judicious in the choice of foods, which is sometimes defined by nutritional information, mainly by assessing the lipid profile of the product (Scollan, Price, Morgan, Huws, \& Shingfield, 2017; Van Cleef et al., 2017). Thus, the beef production chain must modernize and advance in aspects related to handling, feeding, the genetic potential of animals, and the constant improvement of the meat product as well (Casperson et al., 2020). This fact happens due to the lipid profile of the meat, 
composed mainly of trans and saturated fatty acids (Smith, Lunt, Smith, \& Walzem, 2020) since beef has been associated with increased cholesterol, a factor that contributes to the appearance of cardiovascular diseases (Pinho et al., 2012). However, meat is also a source of essential fatty acids to human health, such as conjugated linoleic acid, responsible for preventing various diseases (Pighin et al., 2016).

Given this paradox, the interest in developing nutritional strategies to manipulate the fatty acid composition of beef has been growing, stimulated by the need of producing more healthful meat (Kallas, Realini, \& Gil, 2014; Salami et al., 2021), aiming to reduce its association with diseases of modern life and improve competitiveness with pork and poultry meats. In addition, other aspects also corroborate changes in the lipid content of meat, such as factors intrinsic to animals, emphasizing the breed, sex, and age of the animals (Pires et al., 2008; Rotta et al., 2009).

When evaluating the fatty acid composition of the Longissimus thoracis et luborum (LTL) muscle of steers and heifers finished in feedlot with roughage diet, Fernandes et al. (2009) found no difference in the levels of unsaturated, monounsaturated, and polyunsaturated fatty acids. However, contradictory results define the nature of this knowledge since Reddy et al. (2014) identified that meat from heifers has a better lipid profile when compared to steers, bulls, and cows. However, until this moment, there are no studies that have investigated the relationship between high-grain diets and the lipid composition of meat from feedlot cattle, as well as this combination associated with the sexual condition (males and females) of the animals. Therefore, it is an emerging and necessary topic in the search for healthy foods that meet the new principles of modern consumers, once integrating the perception of consumers in the production chain makes it more competitive and innovative (Mahbubi, Uchiyama, \& Hatanaka, 2019). Therefore, the present study aims to evaluate the fatty acid profile in the LTL muscle of steers and heifers, finished in feedlots and fed with high-grain diets.

\section{Material e Methods}

This study was approved by the Ethics Committee on the Use of Animals of the Federal University of Santa Maria (UFSM), protocol number 145/2014. The experiment was carried out from July to October at the Beef Cattle Laboratory, belonging to the Animal Science Department of the Federal University of Santa Maria, located in the city of Santa Maria, in the physiographic region of the Central Depression of Rio Grande do Sul. The climate of the region is subtropical with a hot and humid summer, according to the Köppen classification (Alvares, Stape, Sentelhas, Gonçalves, \& Sparovek, 2013).

Forty-five Charolais and Nellore crossbred cattle were used, 21 heifers with an initial age of $32 \pm 2$ months and $359.9 \pm$ $6.7 \mathrm{~kg}$ of body weight, and 24 heifers with an initial age of $20 \pm 2$ months and $337.6 \pm 6.2 \mathrm{~kg}$ of body weight. The experimental design was completely randomized, with a $3 \times 2$ factorial arrangement (three diets and two sexual conditions). The animals were distributed in the treatments according to the energy source used in the diet, being them: whole grains of rice; white oats or corn, with seven heifers 
and eight steers in each diet. Prior to the experimental period, the animals were adapted to the facilities and diets for 21 days. During this period, the control of endoparasites was performed, with subcutaneous application of a product based on Albendazole (concentration of $1 \%$ ) in a dosage recommended by the manufacturer.

The cattle were allocated individually in paved and semi-covered stalls, provided with feeders for food supply and waterers with water ad libitum, regulated with a common float faucet for two boxes. During the experimental period, the animals received isonitrogenized diets according to the respective treatment (Table 1). Table 2 contains the lipid profile of the experimental diets used.

The steers were fed with no restriction twice a day, in the morning at 8 am and in the afternoon at $2 \mathrm{pm}$. Previous to the first diet supply, the leftovers from the previous day were collected, which were pre-established between 50 and $80 \mathrm{~g} \mathrm{~kg}^{-1}$ of the food offered.

The animals were sent to slaughter at the end of the experimental period, consisting of 67 or 79 days in the feedlot system. On each of these days, the balanced number of cattle per category and treatment was maintained. The exit weights were $404.4 ; 445.8$ and 421.9 ( \pm 12.8) $\mathrm{kg}$ for steers, and $399.2 ; 453.8$ and 438.8 $( \pm 13.7) \mathrm{kg}$ for heifers, both fed with rice, white oats, and corn, respectively. The slaughter criterion was established by estimating hot carcass weight in the order of $220 \mathrm{~kg}$. Before boarding, the weighings were carried out with 14-hour fasting of solids and liquids. Afterward, the cattle were transported to the commercial slaughterhouse, and the slaughter took place according to the Regulation of Industrial and Sanitary Inspection of Products of Animal Origin - RIISPOA (Decreto 9.023, 2017), following the routine in the slaughter line of the establishment. 


\section{Table 1}

\section{Ingredients and nutritional composition of experimental diets}

\begin{tabular}{|c|c|c|c|}
\hline \multirow{2}{*}{ Component' } & \multicolumn{3}{|c|}{ Diets } \\
\hline & Rice & White Oats & Corn \\
\hline \multicolumn{4}{|l|}{ Ingredients } \\
\hline Corn (g kg MS-1) & - & - & 835.00 \\
\hline White Oats (g kg MS-1) & - & 840.00 & - \\
\hline Rice $\left(\mathrm{g} \mathrm{kg} \mathrm{MS}^{-1}\right)$ & 834.00 & - & - \\
\hline Urea (g kg MS-1) & 9.00 & - & 5.00 \\
\hline Calcitic Limestone (g kg MS ${ }^{-1}$ ) & 7.00 & 10.00 & 10.00 \\
\hline Protein-vitamin-mineral ( $\left.\mathrm{g} \mathrm{kg} \mathrm{MS}^{-1}\right)^{\|}$ & 150.00 & 150.00 & 150.00 \\
\hline \multicolumn{4}{|l|}{ Nutritional Composition } \\
\hline Dry Matter (g kg MN-1) & 891.40 & 906.20 & 897.70 \\
\hline Crude Protein (g kg MS-1) & 142.00 & 149.70 & 141.70 \\
\hline Ether Extract (g kg MS-1) & 18.90 & 43.50 & 37.80 \\
\hline Neutral Detergent Fiber (g kg MS-1) & 224.30 & 310.50 & 159.30 \\
\hline Acid Detergent Fiber (g kg MS-1) & 177.60 & 152.50 & 52.80 \\
\hline Lignin (g kg MS-1) & 57.90 & 37.70 & 13.60 \\
\hline Silica (g kg MS-1) & 22.10 & 6.30 & 4.00 \\
\hline Ash (g kg MS-1) & 99.20 & 76.40 & 52.00 \\
\hline Total Digestive Nutrients (g kg MS-1) & 666.00 & 724.20 & 816.40 \\
\hline Total Carbohydrates (g kg MS-1) & 739.90 & 729.20 & 768.40 \\
\hline Non-Structural Carbohydrates (g kg MS-1) & 553.80 & 438.50 & 636.10 \\
\hline Calcium (g kg MS-1) & 7.80 & 8.80 & 9.50 \\
\hline Phosphorus (g kg MS-1) & 3.90 & 4.90 & 4.00 \\
\hline
\end{tabular}

' DM: Dry Matter; NM: Natural Matter

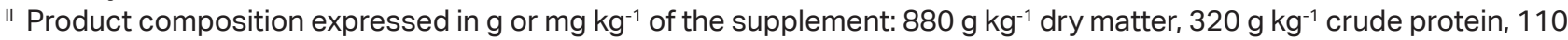
$\mathrm{g} \mathrm{kg}^{-1}$ non-protein nitrogen equivalent in protein, $15 \mathrm{~g} \mathrm{~kg}^{-1}$ ether extract, $150 \mathrm{~g} \mathrm{~kg}-1$ fibrous matter, mineral matter 190 $\mathrm{g} \mathrm{kg}^{-1}$ (including minerals calcium, phosphorus, sodium, copper, iron, iodine, manganese, selenium, cobalt, zinc, and fluorine), minimum $24000 \mathrm{IU} \mathrm{kg}{ }^{-1}$ vitamin A, minimum $6000 \mathrm{IU} \mathrm{kg}^{-1}$ vitamin D3, minimum $140 \mathrm{IU} \mathrm{kg}^{-1} \mathrm{vitamin} \mathrm{E} 15 \mathrm{mg} \mathrm{kg}{ }^{-1}$ flavomycin, $200 \mathrm{mg} \mathrm{kg}^{-1}$ lasalocid. 
Table 2

Lipid profile of ingredients and experimental diets

\begin{tabular}{|c|c|c|c|c|c|c|c|}
\hline \multirow{2}{*}{$\begin{array}{l}\text { Composition } \\
\text { ( } \mathrm{g} \mathrm{kg}^{-1} \text { of lipid) }\end{array}$} & \multicolumn{4}{|c|}{ Ingredients } & \multicolumn{3}{|c|}{ Diets } \\
\hline & Rice & White Oats & Corn & Nucleus & Rice & White Oats & Corn \\
\hline \multicolumn{8}{|l|}{ Saturated } \\
\hline Myristic (C14:0) & 22.80 & 9.10 & 1.50 & 0.00 & 19.02 & 7.64 & 1.25 \\
\hline Palmitic (C16:0) & 290.00 & 185.20 & 118.30 & 155.80 & 265.23 & 178.94 & 122.15 \\
\hline Margaric (C17:0) & 4.80 & 0.00 & 0.70 & 0.00 & 4.00 & 0.00 & 0.58 \\
\hline Stearic (C18:0) & 127.60 & 37.60 & 22.00 & 23.30 & 109.91 & 35.08 & 21.87 \\
\hline Arachidic (C20:0) & 7.80 & 6.20 & 4.60 & 10.00 & 8.01 & 6.71 & 5.34 \\
\hline Behenic (C22:0) & 0.00 & 0.00 & 1.20 & 0.00 & 0.00 & 0.00 & 1.00 \\
\hline Lignoceric (C24:0) & 12.10 & 0.00 & 1.60 & 0.00 & 10.09 & 0.00 & 1.34 \\
\hline \multicolumn{8}{|l|}{ Monounsaturated } \\
\hline Palmitoleic (C16:1 n-7) & 24.20 & 6.70 & 2.40 & 0.00 & 20.18 & 5.63 & 2.00 \\
\hline Elaidic (C18:1 n-9 trans) & 4.00 & 2.40 & 0.70 & 2.70 & 3.74 & 2.42 & 0.99 \\
\hline Oleic (C18:1 n-9 cis) & 361.30 & 360.70 & 277.30 & 311.70 & 348.08 & 349.74 & 278.30 \\
\hline Gondoic (C20:1 n-9) & 26.40 & 22.30 & 2.90 & 27.30 & 26.11 & 22.83 & 6.52 \\
\hline \multicolumn{8}{|l|}{ Polyunsaturated } \\
\hline Linoleic (C18:2 n-6) & 75.50 & 298.10 & 550.80 & 216.20 & 95.40 & 282.83 & 492.35 \\
\hline$\alpha$-linolenic (C18:3 n-3) & 20.00 & 7.00 & 10.50 & 78.80 & 28.50 & 17.70 & 20.59 \\
\hline di homo $y$-linoleic (C20:3n-6) & 23.50 & 0.00 & 2.60 & 67.60 & 29.74 & 10.14 & 12.31 \\
\hline di homo $\alpha$-linoleic (C20:3n-3) & 0.00 & 64.80 & 3.00 & 95.40 & 14.31 & 68.74 & 16.82 \\
\hline Timnodonic (C20:5n-3 EPA) & 0.00 & 0.00 & 0.00 & 1.20 & 0.18 & 0.18 & 0.18 \\
\hline
\end{tabular}

The carcasses were identified and kept in a cooling chamber for 24 hours. In the right half carcass, a portion of the LTL muscle was removed between the 10th and 12th ribs, identified and surrounded by a plastic sheet and brown paper, and stored at $-18^{\circ} \mathrm{C}$. After freezing, a $2.5 \mathrm{~cm}$ thick steak was removed, perpendicular to the length of the muscle. After thawing, which was performed at room temperature, the steaks were dried in a forced ventilation oven at $55^{\circ} \mathrm{C}$, ground with a 1.0 $\mathrm{mm}$ sieve, identified and stored for analysis in the laboratory.
The extraction of lipids was performed using the method of Christie (1982). The fatty acid profile was determined in a gas chromatography apparatus (Agilent, 4581301, USA) equipped with a flame ionization detector and a fused silica capillary column with $100 \mathrm{~m} \times 250 \mu \mathrm{m}$ of diameter (Supelco $2560)$. Nitrogen was used as the carrier gas in a flow of $1.0 \mathrm{~mL} /$ minute and sample injection volume of $1.0 \mu \mathrm{L}$ in $1 / 50$ split mode, being the injection and detection temperature of $250^{\circ} \mathrm{C}$. Fatty acids were identified by comparing the retention times of known methyl ester 
standards(Sigma:SupelcoMix37Components FAME; Linoleic Acid Methyl Ester Mix (cis/ trans); trans-11-Octadecenoic Methyl Ester; Linoleic Acid Conjugated Methyl Ester) and its esterified samples. The quantification of fatty acids in percentage of lipids was carried out using the known concentration of the internal standard of methyl tricosanoate (C23: 0) and the theoretical correction factor, as well as the conversion factor of the methyl ester to fatty acid, according to the methodology proposed by Visentainer (2012). To obtain the delta $9\left(\Delta^{9}\right)$ desaturase index estimates, it was used the equation proposed by Malau-Aduli, Siebert, Bottema and Pitchford (1997): C18 = 100 * [C18: 1n-9 / (C18: 0 + C18: 1n9)].

Statistical analyzes were performed using the SAS statistical package (Statistical Analysis System, version 9.2). A priori, the data collected for each variable were tested for the normality of the residues by the Shapiro-Wilk test, and the transformation was performed when necessary. Subsequently, the data were subjected to analysis of variance by PROC GLM, using the mathematical model below:

$$
Y i j=\mu+\beta i+T j+\left(\beta i^{*} T j\right)+\varepsilon i j ;
$$

where Yij represents the dependent variables; $\mu$ the general mean of the observations; $\beta i$ the effect of the i-th sexual condition of cattle, $\mathrm{Tj}$ the effect of the $j$-th food treatment; $\beta i^{*} T j$ the interaction between the i-th sexual condition and the j-th food treatment, and $\varepsilon i j$ the random residual error. The means were classified by the $\mathrm{F}$ test and the parameters with significant effect compared by the " $\mathrm{t}$ " test with $\alpha=0.05$. Finally, all interactions with a significant effect were unfolded and their means compared at a significance level of $5 \%$ using the " $t$ " test. The unfoldings were made operational by the $\mathrm{R}$ software, version 3.6.2 (R Core Team [R],
2019), using the 'easyanova' package through the 'ea1' function (Arnhold, 2013).

\section{Results and Discussion}

In evaluating saturated acids, it was observed that stearic acid had greater participation in the meat of animals that received rice or white oats (Table 3 ). This fatty acid is considered neutral and does not alter blood cholesterol levels. In addition, it can be converted into oleic acid, which consumption is beneficial to health. Feeding animals with corn resulted in a higher concentration of pentadecylic and margaric acids. According to Fernandes et al. (2009), odd-chain fatty acids are uncommon; however, they are formed by the De Novo synthesis of propionic acid during rumen fermentation, which is more noticeable in the digestion of corn than in other grains. In particular, pentadecylic is a fatty acid synthesized by ruminal bacteria and found in low concentration in bovine muscle (Van Cleef et al., 2017). However, according to these authors, the higher concentration of pentadecylic in the rumen environment and, subsequently, the meat is due to the environment suitable for microbial growth in the rumen.

Regarding monounsaturated fatty acids, it is observed that the content of 10-heptadecenoic acid was higher in the meat of animals fed with corn compared to those fed with rice or white oats (Table 3 ). The oleic acid content was higher in animals fed with white oats than those that received corn (Table 3), which is the main monounsaturated fatty acid found in the meat of cattle. The two fatty acids have hypocholesterolemic properties and are considered beneficial in 
reducing LDL cholesterol and raising HDL cholesterol. Of all fatty acids, Choi, Kwon and Kim (2016) observed that oleic represents around $90 \%$ of monounsaturated ones, as observed in our study. In addition, the mean values obtained for the diets of the present study were higher than those verified by Freitas et al. (2014) and Fruet et al. (2018), who did not observe changes in the oleic acid content among beef from cattle finished in pasture or feedlot, with the presence of grains in the diet. In turn, Costa et al. (2012) found an interaction between diet and breed on the oleic acid profile, with superiority for the Barrosã breed in both low and high forage inclusion diets, but with no differentiation for the meat of Alantejana cattle, regardless of the level of forage inclusion. However, further studies are needed to clearly understand the association of the diet and the fermentation rate combined with the deposition of oleic acid in the meat, since when speculating the effect of the neutral detergent fiber content, the results of the present study differ from those found by Costa et al. (2012).
The white oat diet promoted an increase in the elaidic acid content (Table 3). This fatty acid is one of the predominant in fats that undergo hydrogenation, being the main competitor of the linoleic in human metabolism, and this action may reflect on the reduction of the number of LDL receptors contributing to the increase of its plasma levels (Chiara, Sichieri, \& Carvalho, 2003). Although unsaturated, elaidic acid, formed in a lower proportion than the vaccenic one in partial hydrogenation, induces the formation of atheromatous plaques and increases the level of LDL cholesterol and triglycerides in the blood (Bassett et al., 2010), presenting, therefore, a behavior of saturated fatty acid. Also, heifers had a $28.50 \%$ higher elaidic acid content than steers (Table 3). According to Zhang, Liu, Brown and Wu (2015), the sex of animals affects the composition of fatty acids in meat, as they determine differences in the deposition of body fat. The values obtained for steers are similar to those obtained by Freitas et al. (2014), who found $0.27 \%$ of elaidic acid in the meat of steers finished in pasture and feedlot, with equivalent age to those of the present study. 


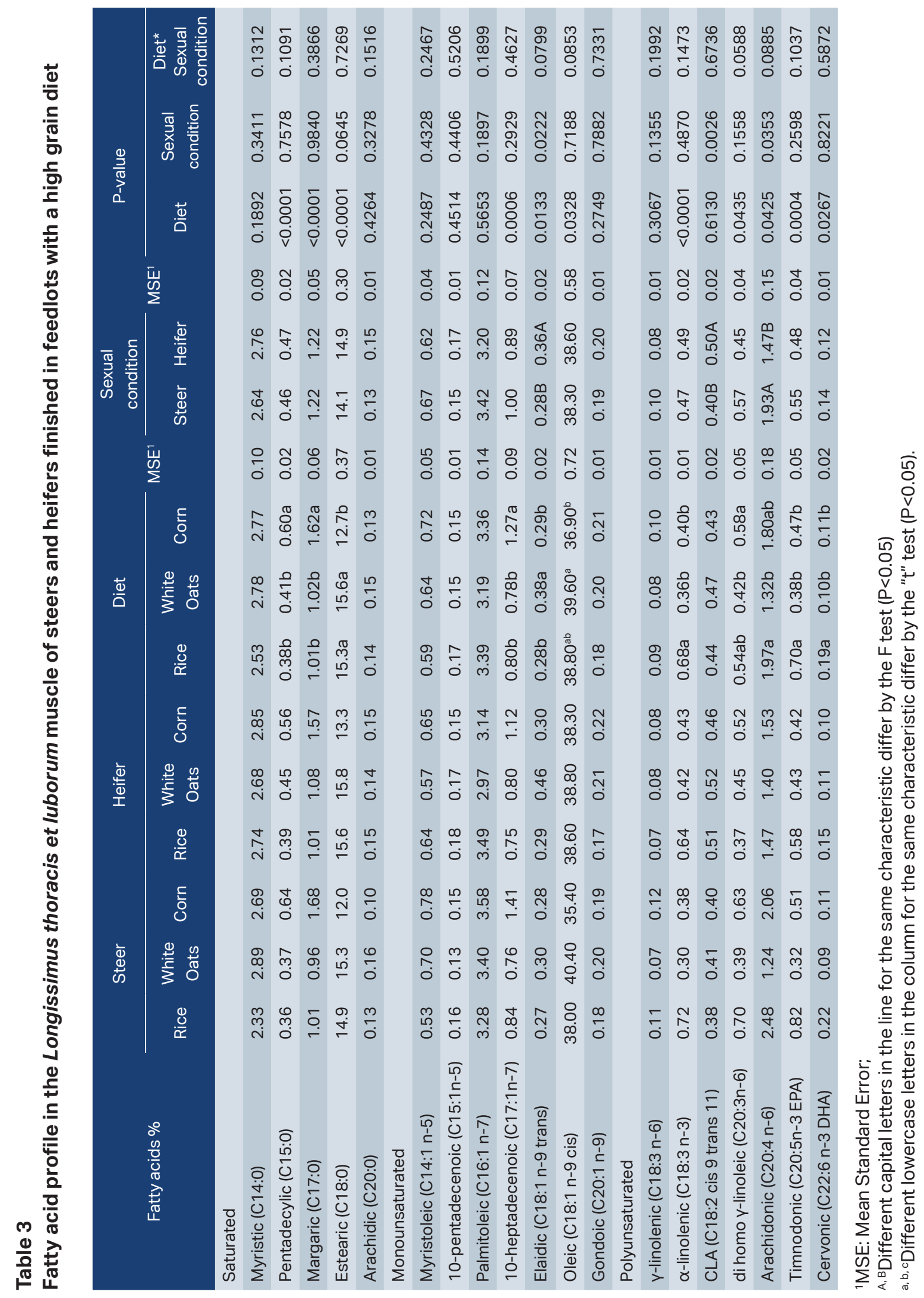


About polyunsaturated fatty acids, cattle fed with rice had higher levels of thymnodonic and cervonic acids (Table 3) and, consequently, had higher omega-3. McNamara (2016) pointed out that diets deficient in omega-3 fatty acids may represent risk factors for developing depression and cardiovascular diseases. Based on these results, the inclusion of rice in the diet of feedlot cattle is an alternative for the increase of omega-3 fatty acids in meat. This would improve the nutraceutical profile and possibly the acceptability of consumers (Nassu et al., 2011; Kallas et al., 2014), in addition to reducing the incidence of chronic diseases (Scollan et al., 2017) and to adding value to meat.

The diets did not alter the CLA deposition (Table 3), although the activity of the enzyme $\Delta 9$ desaturase was higher in animals fed with corn (Table 4). The CLA levels observed in the present study are higher than those reported by Silva et al. (2014) in feedlot steers receiving $20 \%$ of corn silage and $80 \%$ of concentrate in the diet. These results demonstrate that it is possible to increase the CLA content in meat by increasing the fraction concentrated in the diet of feedlot cattle and, in sequence, to optimize consumer appreciation for meat products due to the health benefits of this fatty acid, as anticarcinogenic, antiobesity and antidiabetic effects, and antihypertensive properties (Koba \& Yanagita, 2014). This occurs due to the high proportions of grains in the diet that decrease the population of microorganisms in the rumen, which are responsible for the isomerization and biohydrogenation of polyunsaturated fatty acids. Consequently, there is a reduction in $\mathrm{pH}$ in the rumen environment, which determines a faster passage of these fatty acids without conversion to saturated.
The heifers presented meat with a higher CLA content than the steers, which must be associated with the older age of the females. Pires et al. (2008) pointed out that among the factors that alter the CLA deposition are the age and sex of the animals. Sex is important in determining the quality of meat, as it affects the deposition of muscle and fat tissues. Thus, we can manipulate the fatty acid deposition profile to produce more healthful beef for consumers by selecting cattle considering their sexual condition associated with adequate diets.

The content of monounsaturated fatty acids was not influenced by diet or sexual condition and represented a mean value of $46 \%$ of the total fatty acids. This increase in monounsaturated fatty acid content is relevant and can be considered a positive aspect of meat from cattle in feedlot systems. According to Van Elswyk and McNeill (2014), cattle finished in pasture produce meat with a lower content of monounsaturated fatty acids than animals fed with grains, reducing the relationship between monounsaturated and saturated fatty acids, a fact that can lead to a decrease in HDL and elevation of LDL and triglycerides levels in humans (Gilmore et al., 2011).

The relationship between the total content of unsaturated and saturated fatty acids was higher in animals fed with corn (Table 4). This result is justified by the higher saturation of fatty acids in animals fed with white oats and rice and greater polyunsaturation in animals fed with corn. Thus, using techniques that improve the relationship between unsaturated/saturated fatty acids can make beef more healthful for human consumption. Among sexual conditions, heifers showed a lower relationship between unsaturated and saturated fatty acids, a fact that must be related to the older age of the animals, as this implies a greater degree of fatty acids saturation. 


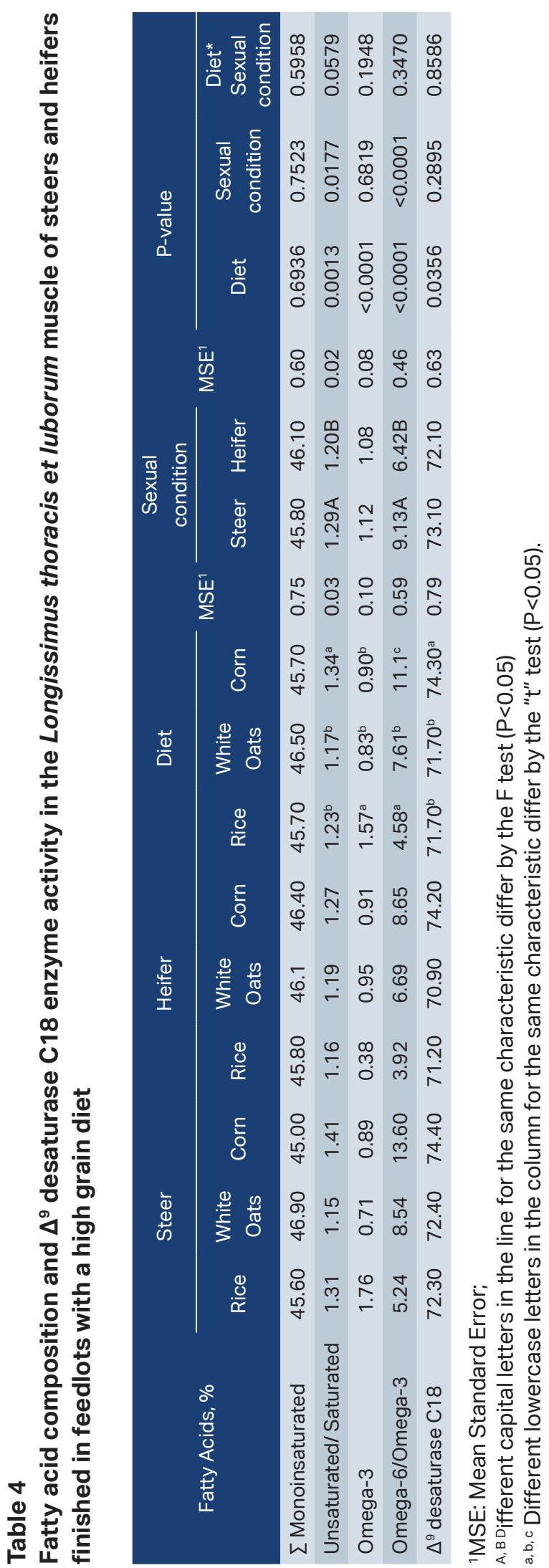




\section{Table 5}

Unfold interaction for the fatty acid profile in the Longissimus thoracis et luborum muscle of steers and heifers finished in feedlots with a high grain diet

\begin{tabular}{|c|c|c|c|c|c|c|c|}
\hline \multirow[b]{2}{*}{ Fatty Acid (\%) } & \multirow{2}{*}{$\begin{array}{l}\text { Sexual } \\
\text { condition }\end{array}$} & \multicolumn{3}{|c|}{ Diet } & \multirow[b]{2}{*}{ Mean } & \multirow[b]{2}{*}{ MSE' } & \multirow{2}{*}{$\begin{array}{c}\text { P-Value } \\
\text { Diet } \times \text { Sexual } \\
\text { condition }\end{array}$} \\
\hline & & Rice & White Oats & Corn & & & \\
\hline \multirow{3}{*}{ Palmitic (C16:0) } & Steer & $24.50 \mathrm{Bb}$ & $26.80 A a$ & $24.60 \mathrm{Ab}$ & 25.30 & & \\
\hline & Heifer & 26.90Aa & $25.70 A a$ & $25.40 \mathrm{Aa}$ & 26.00 & 0.50 & 0.0047 \\
\hline & Mean & 25.70 & 26.20 & 25.00 & & & \\
\hline \multirow{3}{*}{$\begin{array}{c}\text { Vaccenic } \\
\text { (C18:1 n-11 } \\
\text { trans) }\end{array}$} & Steer & $1.25 \mathrm{Ab}$ & $1.00 \mathrm{Bb}$ & $3.23 \mathrm{Aa}$ & 1.83 & & \\
\hline & Heifer & $1.69 \mathrm{Aa}$ & 2.10Aa & $2.47 \mathrm{Aa}$ & 2.09 & 0.33 & 0.0068 \\
\hline & Mean & 1.47 & 1.55 & 2.85 & & & \\
\hline \multirow{3}{*}{$\begin{array}{l}\text { Linoleic } \\
\text { (C18:2 n-6) }\end{array}$} & Steer & $5.65 \mathrm{Ab}$ & $4.01 \mathrm{Ab}$ & $9.00 \mathrm{Aa}$ & 6.22 & & \\
\hline & Heifer & $3.54 \mathrm{Bb}$ & 4.58Aab & $6.13 \mathrm{Ba}$ & 4.75 & 0.60 & 0.0182 \\
\hline & Mean & 4.60 & 4.30 & 7.57 & & & \\
\hline \multirow{3}{*}{$\Sigma$ Saturated } & Steer & $43.40 \mathrm{Bb}$ & 46.50Aa & 41.40Ab & 43.80 & & \\
\hline & Heifer & 46.80Aa & 45.90Aab & 44.10Ab & 45.60 & 0.80 & 0.0352 \\
\hline & Mean & 45.10 & 46.20 & 42.70 & & & \\
\hline \multirow{3}{*}{$\frac{\Sigma}{\text { Polyunsaturated }}$} & Steer & 11.20Aa & $6.85 \mathrm{Ab}$ & $12.70 \mathrm{Aa}$ & 10.30 & & \\
\hline & Heifer & $7.25 \mathrm{Ba}$ & 8.19Aa & $9.00 \mathrm{Ba}$ & 8.14 & 1.06 & 0.0323 \\
\hline & Mean & 9.23 & 7.52 & 10.90 & & & \\
\hline \multirow{3}{*}{ Omega-6 } & Steer & 8.94Ab & $5.72 A c$ & $11.5 \mathrm{Aa}$ & 8.72 & & \\
\hline & Heifer & $5.36 \mathrm{Bb}$ & 6.70Aab & 7.63Ba & 6.56 & 0.96 & 0.0261 \\
\hline & Mean & 7.15 & 6.21 & 9.57 & & & \\
\hline
\end{tabular}

${ }^{1} \mathrm{MSE}:$ Mean Standard Error;

A, B Means followed by capital letters in the column for the same characteristic indicate a difference for the sexual condition within the diet by the " $t$ " test $(P<0.05)$.

$a, b, c$ Means followed by lowercase letters in the line for the same characteristic indicate a difference for diets within the sexual condition by the " $t$ " $(P<0.05)$.

There was an interaction between diet and sexual condition for the ômega- 6 fatty acid group (Table 5). Thus, it was identified that the steers showed a greater presence of these fatty acids when fed with corn in relation to the other diets. In turn, rice supply to the steers promoted a higher content of omega- 6 compared to white oats. The corn diet caused a higher omega- 6 content for heifers than rice, while white oats had an intermediate behavior. When evaluating sexual conditions within each diet, the steers showed a higher omega content in the meat in diets with rice and corn. Cattle that received rice had a higher content of omega-3 in the meat, which must be related to the higher concentration of $\alpha$-linolenic acid in the rice grain (Table 2 ), which is a precursor of fatty acids of the omega-3 family. These results influenced the omega-6/omega-3 ratio, which was 4.58, 7.61, and 11.1 for cattle fed with rice, white oats, and corn, respectively. A result similar to that 
of the present study was obtained by Aldai et al. (2010), in which diets based on distillery dry grains (DDGs) of wheat had a higher content of $\alpha$-linolenic acid than diets based on corn DDGs, which led to a decrease in the omega-6/ omega-3 ratio. The adequate ratio between omega- 6 and omega- 3 fatty acids should preferably be less than 4:1 (Pinho et al., 2011). Therefore, only the rice grain diet was close to the desired reference value. Given this, it was already expected that grain-based diets normally low in $\alpha$-linolenic acid could result in disadvantages for the omega-6/omega-3 ratio. Animals fed on forage produce meat with a higher concentration of omega-3 without changing omega-6, improving the omega-6/ omega-3 ratio (Daley, Abbot, Doyle, Nader, \& Larson, 2010).

\section{According to Patterson, Wall,} Fitzgerald, Ross and Stanton (2012), the increase in the omega-6/omega-3 ratio can raise the production of thromboxanes and leukotrienes, which in excess are associated with cardiovascular diseases, thrombosis, arthritis, and obesity. Among the challenges in meat production is obtaining products with a higher content of omega-3 due to the beneficial factors to human health. Researches have shown that omega-3 fatty acids are important for physical and mental health, preventing problems such as depression, attention deficit and hyperactivity (Lange, 2020). Mazzucco et al. (2016) reported that diets with omega-6 fatty acids are easily obtained from various foods. However, foods with an adequate omega-3 content are scarce, which can be obtained with rice inclusion in the cattle diet. Thus, improving the quality standard of beef is important for consumer satisfaction and the meat industries by increasing economic gain. In this sense, heifers showed a lower ratio between omega-6/omega-3 fatty acids in meat, corroborating with studies that identified that this sexual condition has higher quality meat and a more healthful composition in terms of fatty acids when compared to steers, cows, and bulls (Venkata Reedy et al., 2014).

Among the saturated fatty acids, there was an interaction between diet and sexual condition for palmitic one (Table 5). In this sense, the steers fed with white oats exhibited a greater increase of this acid in relation to the grains of rice and corn. Otherwise, there was no difference in diets for palmitic concentration in the meat of heifers. When the sexual condition was evaluated according to the diets, there was a difference only for rice, in which heifers had a higher palmitic acid content. Palmitic acid, as the myristic one, are undesirable once both have a hypercholesteremic effect. According to Daley et al. (2010), myristic has the potential to raise the plasma cholesterol concentration four times higher than palmitic acid.

Similarly, there was an interaction for the content of vaccenic fatty acid (Table $5)$, once in the meat of steers, the feeding with corn increased by 1.98 and $2.23 \%$ the participation of this fatty acid, respectively, in relation to the rice and white oats. The vaccenic content did not change according to the diets when used in the feeding of heifers. Among sexual conditions, only white oats feed differed for vaccenic, indicating that heifers were superior to steers. According to Daley et al. (2010), vaccenic acid is an important precursor in the intermediate metabolism of conjugated linoleic acid (CLA), responsible for 80 to $90 \%$ of CLA in meat intramuscular fat. The consumption of meat with higher content of vaccenic acid is desirable since CLA accumulation in humans is greater when $\mathrm{C} 18: 1$ 
n-11 trans intake occurs (Larqué, Zamora, \& Gil, 2001). It is suggested that the higher concentration of vaccenic for steers and heifers fed with corn grain is related to the lower content of neutral detergent fiber in this diet (Table 1). This may have provided optimization of the fermentation rate and consequently reduced biohydrogenation, which leads to greater deposition of intermediate fatty acids in the meat. Similarly, Fruet et al. (2018) found higher concentrations of the sum of C18:1 n-9 trans, C18:1 n-10 trans, and C18:1 n-11 trans in steers fed without roughage compared to steers fed with pasture or pasture with supplementation.

There was an interaction between diet and sexual condition for linoleic acid $(P$ $<0.05)$. Steers that received corn showed a higher concentration of this fatty acid (Table 5) compared to the other diets used, which must be related to its high presence in corn (Table 2 ). However, among heifers, rice feeding resulted in a lower linoleic content than corn one, while white oats were similar to the other grains. The cattle fed with rice had a higher content of $\alpha$-linolenic acid, which must be associated with its higher rice grain concentration. This fatty acid, together with the linoleic one, is considered essential for humans since both of them are not synthesized by the organism (Oliveira et al., 2011). In addition, interaction (diet and sexual condition) is observed for the total saturated fatty acids in the meat (Table 5). The steers fed with white oats presented a lipid profile of $2.10 \%$ more saturated in relation to those that received rice and $5.10 \%$ to those fed with corn. However, heifers from rice treatment showed a $2.70 \%$ higher concentration of saturated fatty acids than those that received corn, with an intermediate behavior for white oats.
Finally, there was also interaction for the sum of polyunsaturated fatty acids (Table 5). Steers fed with white oats showed a significant reduction in the polyunsaturated content in relation to the steers that received the other diets. There was no difference between heifers in the content of polyunsaturated fatty acids. Therefore, the desirable lipid profile can be found in the meat of steers finished with high grain diets based on rice and corn. In diets with corn grain, the polyunsaturated content followed the variations observed for linoleic acid for both sexual conditions (Table 5), which is the main polyunsaturated fatty acid in beef. In addition, steers fed with rice or corn have a higher polyunsaturated content than heifers. In general, it is observed in the present study that the main fatty acids present in beef are unsaturated. This must be associated with the high-grain dietused, which probably decreased the ruminal $\mathrm{pH}$ and reduced biohydrogenation, favoring the absorption of unsaturated fatty acids in the post-rumen. Scollan et al. (2014) reported that high-concentrate diets affect ruminal biohydrogenation and alter the flow of fatty acids to the duodenum, influencing the deposition of fatty acids in the muscles.

\section{Conclusion}

The finishing of cattle with a high grain diet based on rice is advantageous when meat production with a higher fatty acid content of the omega-3 group is recommended. When finished in feedlot systems with high grain diets, heifers produce meat with higher CLA content and a better ratio of omega-6/omega-3 fatty acids in relation to steers. Finally, these findings indicate that it is possible to modify the profile of meat fatty acids through changes in food management and, consequently, to meet the 
requirements of a modern population, which is redefining its principles concerning food.

\section{References}

Aldai, N., Dugan, M. E. R., Aalhus, J. L., McAllister, T. A., Walter, L. J., \& McKinnon, J. J. (2010). Differences in the trans-18:1 profile of the backfat of feedlot steers fed wheat or corn based dried distillers' grain. Animal Feed Science and Technology, 157(3-4), 168-172. doi: 10.1016/j.anifeedsci.2010. 03.009

Alvares, C. A., Stape, J. L., Sentelhas, P. C., Gonçalves, J. L. M., \& Sparovek, G. (2013). Köppen's climate classification map for Brazil. Meteorologische Zeitschrift, 22(6), 711-728. doi: 10.1127/0941-2948/2013/ 0507

Arnhold, E. (2013). Package in the R environment for analysis of variance and complementary analyses. Brazilian Journal of Veterinary Research and Animal Science, 50(6), 488-492. doi: 10.11606/ issn.1678-4456.v50i6p488-492

Bassett, C. M., Edel, A. L, Patenaude, A. F., McCullough, R. S., Blackwood, D. P., Chouinard, P. Y.,... Pierce, G. N. (2010). Dietary vaccenic acid has antiatherogenic effects in LDLr-/- mice. The Journal of Nutrition, 140(1), 18-24. doi: 10.3945/jn. 109.105163

Casperson, S. L., Conrad, Z., Raatz, S. K., Derner, J., Roemmich, J. N., Jahns, L., \& Picklo, M. J. (2020). Impact of beef consumption on saturated fat intake in the United States adult population: Insights from modeling the influences of bovine genetics and nutrition. Meat Science, 169, 108225. doi: 10.1016/j.meatsci.2020.108225
Chiara, V. L., Sichieri, R., \& Carvalho, T. S. F. (2003). Teores de ácidos graxos trans de alguns alimentos consumidos no Rio de Janeiro. Revista de Nutrição, 16(2), 227233. doi: 10.1590/S1415-52732003000 200010

Choi, C. B., Kwon, H., \& Kim, S. I. (2016). Effect of rice bran, flax seed, and sunflower seed on growth performance, carcass characteristics, fatty acid composition, free amino acid and peptide contents, and sensory evaluations of native Korean cattle (Hanwoo). Asian-Australian Journal Animal Science, 29(2), 195-203. doi: 10.57 13/ajas.15.0264

Christie, W. W. (1982). A simple procedure for rapid transmethylation of glycerolipids and cholesteryl esters. Journal of Lipid Research, 23(7), 1072-1075. Recovered from https://www.jlr.org/article/S0022-22 75(20)38081-0/pdf

Costa, F. S., Cabral, A. R., Silva, S. L., Silva, M. A. I., Henrique, W., Mazalli, Baldi, F. S.; Mueller, L. F.; Ferrinho, M. F.; Corte, R. P. S.; Pereira, A. S. C. (2020). Effects of n-3 and n-6 feeding sources on the quality and lipid oxidation of meat from feedlot-finished Bos indicus steers. Meat Science, 161, 107966. doi: 10.1016/j.meatsci.2019.107966

Costa, P., Lemos, J. P., Lopes, P. A., Alfaia, C. M., Costa, A. S. H., Bessa, R. J. B., \& Prates, J. A. M. (2012). X'beef breeds. Animal, 6(7), 1187-1197. doi: 10.1017/S1751731 111002722

Daley, C. A., Abbot, A., Doyle, P. S., Nader, G. A., \& Larson, S. (2010). A review of fatty acid profiles and antioxidant content in grassfed and grain-fed beef. Nutrition Journal, 9(10), 1-12. doi: 10.1186/1475-2891-9-10 
Decreto n. 9.023, de 29 de março de 2017. Dispõem sobre a inspeção industrial e sanitária de produtos de origem animal. Recuperado de http://www.planalto. gov.br/ccivil_03/_ato2015-2018/2017/ decreto/d90 $13 . \mathrm{htm}$

Fernandes, A. R. M., Sampaio, A. A. M., Henrique, W., Tullio, R. R., Oliveira, E. A., \& Silva, T. M. (2009). Composição química e perfil de ácidos graxos da carne de bovinos de diferentes condições sexuais recebendo silagem de milho e concentrado ou canade-açúcar e concentrado contendo grãos de girassol. Revista Brasileira de Zootecnia, 38(4), 705-712. doi: 10.1590/ S1516-35982009000400017

Freitas, A. K., Lobato, J. F. P., Cardoso, L. L., Tarouco, J. U., Vieira, R. M., Dillengurg, D. R., \& Castro, I. (2014). Nutritional composition of the meat $f$ Hereford and Braford steers finished on pastures or in a feedlot in southern Brazil. Meat Science, 96(1), 353360. doi: 10.1016/j.meatsci.2013.07.021

Fruet, A. P. B., Trombetta, F., Stefanello, F. S., Speroni, C. S., Donadel, J. Z., Souza, A. N. M.,... Nörnberg, J. L. (2018). Effects of feeding legume-grass pasture and different concentrate levels on fatty acid profile, volatile compounds, and off-flavor of the M. longissimus thoracis. Meat Science, 14O(6), 112-118. doi: 10.1016/j. meatsci.2018.03.008

Gilmore, L. A., Walzem, R. L., Crouse, S. F., Smith, D. R., Adams, T. H., Vaidyanathan, V.,... Smith, S. B. (2011). Consumption of high-oleic acid ground beef increases HDL-cholesterol concentration but both high- and low-oleic acid ground beef decrease HDL particle diameter in normocholesterolemic men. Journal of
Nutrition, 141(6), 1188-1194. doi: 10.39 45/jn.110.136085

Kallas, Z., Realini, C. E., \& Gil, J. M. (2014). Health information impact on the relative importance of beef attributes including its enrichment with polyunsaturated fatty acids (omega-3 and conjugated linoleic acid). Meat Science, 97(4), 497-503. doi: 10.1016/j.meatsci.2014.03.015

Koba, K., \& Yanagita, T. (2014) Health benefits of conjugated linoleic acid (CLA). Obesity Research \& Clinical Practice, 8(6), 525532. doi: 10.1016/j.orcp.2013.10.001

Lange, K. W. (2020). Omega-3 fatty acids and mental health. Global Health Journal, 4(1), 18-30. doi: 10.10 16/j.glohj.2020.01.004

Larqué, E., Zamora, S., \& Gil, A. (2001) Dietary trans fatty acids in early life: a review. Early Human Development, 65(2), 31-41. doi: 10.1016/S0378-3782(01)00201-8

Mahbubi, A., Uchiyama, T., \& Hatanaka, K. (2019). Capturing consumer value and clustering customer preferences in the Indonesian halal beef market. Meat Science, 156, 2332. doi: 10.1016/j.meatsci.2019.05.012

Malau-Aduli, A. E. O., Siebert, B. D., Bottema, C. D. K., \& Pitchford, W. S. (1997). A comparison of the fatty acid composition of tryacilglycerols in adipose tissue from Limousin and Jersey cattle. Australian Journal of Agricultural Research, 48(5), 715-722. doi: 10.1071/A96083

Mazzucco, J. P., Goszczynski, D. E., Ripoli, M. V., Melucci, L. M., Pardo, A. M., Colatto, E.,... Villareal, E. L. (2016). Growth, carcass and meat quality traits in beef from Angus, Hereford and cross-breed gazing steers, and their association with SNPs in genes related to fat deposition metabolism. Meat 
Science, 114, 121-129. doi: 10.1016/j. meatsci.2015.12.018

McNamara, R. K. (2016). Role of omega-3 fatty acids in the etiology, treatment, and prevention of depression: Current statusand future directions. Journal of Nutrition \& Intermediary Metabolism, 5, 96-106. doi: 10.1016/j.jnim.2016.04.004

Nassu, R. T., Dugan, M. E. R., He, M. L., McAllister, T. A., Aalhus, J. L., Aldai, N., \& Kramer, J. K. (2011). The effects of feeding flaxseed to beef cows given forage based diets on fatty acids of longissimus thoracis muscle and backfat. Meat Science, 89(4), 469477. doi: 10.1016/j.meatsci.2011.05.016

Oliveira, D. M., Ladeira, M. M., Chizzotti, M. L., Machado, O. R., Neto, Ramos, E. M., Gonçalves, T. M.,... Ribeiro, J. S. (2011). Fatty acid profile and qualitative characteristics of meat from Zebu steers fed with different oilseeds. Journal of Animal Science, 89(8), 2546-2555. doi: 10.2527/jas.2010-3553

Patterson, E., Wall, R., Fitzgerald, G. F., Ross, R. P., \& Stanton, C. (2012). Health implications of high dietary omega- 6 polyunsaturated fatty acids. Journal of Nutrition and Metabolism, 2012, 539426. doi: $10.1155 / 2012 / 539426$

Pighin, D., Pazos, A., Chamorro, V., Paschetta, F., Cunzolo, S., Godoy, F.,... Grigioni, G. (2016). A contribution of beef to human health: a review of the role of the animal production systems. The Scientific World Journal, 2016, 8681491. doi: 10. 1155/2016/8681491

Pinho, A. P. S., Barcellos, J. O. J., Peripolli, V., Kindlein, L., Araújo, J. R., \& Alves, D. C., Fo. (2011). Perfil lipídico da gordura intramuscular de cortes e marcas comerciais de carne bovina. Revista Brasileira de Zootecnia, 40(5), 11341142. doi: $10.1590 / S 1516-3598201100$ 0500027

Pinho, C. P. S., Diniz, A. S., Arruda, I. K. G., Lira, P. I. C., Siqueira, L. A. S., \& Batista, M., Fo. (2012). Consumo de alimentos protetores e preditores do risco cardiovascular em adultos do estado de Pernambuco. Revista de Nutrição, 25(3), 341-351. doi: 10.1590/S1415-52732012000300004

Pires, I. S. C., Rosado, G. P., Costa, N. M. B., Monteiro, J. B. R., Oliveira, R. S., Jaeger, S. M. P. L., \& Mourão, D. M. (2008). Composição centesimal e perfil de ácidos graxos da carne de novilho precoce alimentado com lipídeos protegidos. Ciência e Tecnologia de Alimentos, 28(Suppl.), 178-183. doi: 10.1590/S0101-20612008000500028

R Core Team (2019). R: A language and environment for statistical computing. Vienna, Austria: R Foundation for Statistical Computing. Retrieved from https://www.R-project.org/

Reddy, B. V., Sivakumar, A. S., Jeong, D. W., Woo, Y.-B., Park, S.-J., Lee, S.-Y.,... Hwang, I. (2014). Beef quality traits of heifer in comparison with steer, bull and cow at various feeding environments. Animal Science Journal, 86(1), 1-16. doi: 10.1111/ asj.12266

Rotta, P. P., Prado, R. M., Prado, I. N., Valero, M. V., Visentainer, J. V., \& Silva, R. R. (2009). The effects of genetic groups, nutrition, finishing systems and gender of brazilian cattle on carcass characteristics and beef composition and appearance: A review. Asian-Australasian Journal of Animal Sciences, 22(12), 1718-1734. doi: 10.5713/ajas.2009.90071 
Salami, S., O'Grady, M. N., Luciano, G., Priolo, A., McGee, M., Moloney, A. P., \& Kerry, J. P. (2021). Fatty acid composition, shelf-life and eating quality of beef from steers fed corn or wheat dried distillers' grains with solubles in a concentrate supplement to grass silage. Meat Science, 173, 108381. doi: 10.1016/j.meatsci.2020.108381

Scollan, N. D., Dannenberger, D., Nuernberg, K., Richardson, I., MacKintosh, S., Hocquette, J. F., \& Moloney, A. P. (2014). Enhancing the nutritional and health value of beef lipids and their relationship with meat quality. Meat Science, 97(3), 384-394. doi: 10.1016/j.meatsci.2014.02.015

Scollan, N. D., Price, E. M., Morgan, S. A., Huws, S. A., \& Shingfield, K. J. (2017). Can we improve the nutritional quality of meat? Proceedings of the Nutrition Society, 76(4), 603-618. doi: 10.1017/s00296651 17001112

Silva, R. M., Restle, J., Missio, R. L., Lage, M. E., Pacheco, P. S., Bilego, U. O., Pádua, J. T., \& Fausto, D. A. (2014). Perfil de ácido graxos na carne de novilhos europeus e zebuínos alimentados com milheto. Pesquisa Agropecuária Brasileira, 49(1), 63-70. doi: 10.1590/S0100-204X2014000100009

Smith, S. B., Lunt, D. K., Smith, D. R., \& Walzem, R. L. (2020). Producing higholeic acid beef and the impact of ground beef consumption on risk factors for cardiovascular disease: a review. Meat Science, 163, 108076. doi: 10.1016/j. meatsci.2020.108076
Van Cleef, E. H. C. B., D'Áurea, A. P., Fávaro, V. R., Van Cleef, F. O. S., Barducci, R. S., Almeida, M. T. C.,... Ezequiel, J. M. B. (2017). Effects of dietary inclusion of high concentrations of crude glycerin on meat quality and fatty acid profile of feedlot fed Nellore bulls. Plos One, 12(6), e0179830. doi: 10.1371/ journal.pone.0179830

Van Elswyk, M. S., \& McNeill, S. H. (2014). Impact of grass/forage feeding versus grain finishing on beef nutrients and sensory quality: the US experience. Meat Science, 96(1), 535-540. doi: 10.1016/j. meatsci.2013.08.010

Venkata Reedy, B., Sivakumar, A. S., Jeong, D. W., Woo, Y. B., Park, S. J., Lee, S. Y.,... Hwang, I. (2014). Beef quality traits of heifer in comparison with steer, bull and cow at various feeding environment. Animal Science Journal, 86(1), 1-16, doi: 10.1111/asj.12266

Visentainer, J. V. (2012). Aspectos analíticos da resposta do detector de ionização em chama para ésteres de ácidos graxos em biodiesel e alimentos. Química Nova, 35(2), 274-279. doi: 10.1590/S0100-404 22012000200008

Zhang, S. G., Liu, S. G., Brown, M. A., \& Wu, J. P. (2015). Comparison of longissimus dorsi fatty acids profiles in gansu black yak and chinese yellow cattle steers and heifers. Korean Journal for Food Science of Animal Resources, 35(3), 286-292. doi: 10.5851/kosfa.2015.35.3.286 